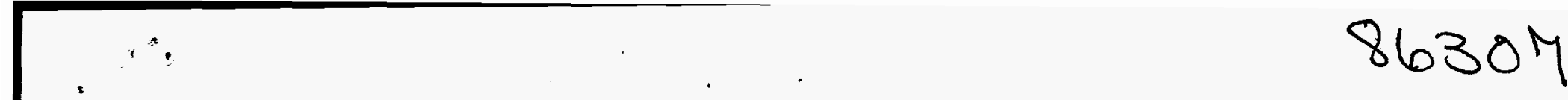
LECEIVED Alli 04 1997

oSTI

ANL/CTD/PP- -86307

\title{
GAS EVOLUTION DURING VITRIFICATION OF SODIUM SULFATE AND SILICA
}

\author{
W. L. Ebert, S. D. Rosine', and A. J. Bakel \\ ARGONNE NATIONAL LABORATORY \\ Chemical Technology Division \\ 9700 South Cass Avenue \\ Argonne, IL 60439 U.S.A.
}

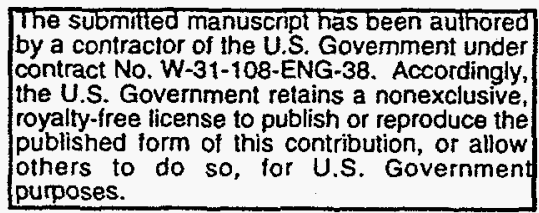

For consideration in

WASTE MANAGEMENT

This work was supported by the U. S. Department of Energy, Office of Technology Development, under Contract W-31-109-ENG-38.

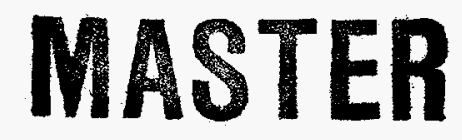

DISTRIBUTION OF THIS DOCUMENT IS UNLIMITED

'Virginia Polytechnical Institute and State University, Blacksburg, VA 


\section{DISCLAMMER}

Portions of this document may be illegible in electronic image products. Images are produced from the best available original docoment. 


\title{
GAS EVOLUTION DURING VITRIFICATION OF SODIUM SULFATE AND SILICA
}

W. L. Ebert, S. D. Rosine, and A. J. Bakel

ARGONNE NATIONAL LABORATORY

\begin{abstract}
This paper describes the operation of an apparatus designed to identify species evolved during vitrification of hazardous waste materials and to measure the temperatures at which they are evolved. To demonstrate the utility of the apparatus for designing off-gas systems, we present the results of heating various sulfates alone and in the presence of silica. During vitrification, the decomposition behavior of some waste components will be affected by the chemical composition of the melt. For example, we found that when silica is present during heating, $\mathrm{SO}_{\mathrm{x}}$ gases are evolved at lower temperatures than when pure sodium sulfate is heated. Such analyses will be important in the design of off-gas units for waste vitrification systems.
\end{abstract}




\section{INTRODUCTION}

Vitrification is being used to treat various hazardous and radioactive waste streams for disposal (1-3). Waste streams are mixed with glass-forming chemicals and melted in a furnace to produce a physically and chemically stable solid waste form in which many hazardous components become chemically bound in a durable glass matrix (usually a silica-based glass). Some components of the waste stream are volatile at typical vitrification temperatures of 1050 to $1150^{\circ} \mathrm{C}$, and so must be captured from the off-gas and further treated as a secondary waste stream. To design off-gas systems, one must know the gases to be captured and treated and the temperatures at which they are evolved.

The evolution of gases during sublimation, evaporation, or decomposition of materials has been studied using various thermal techniques, including differential thermal analysis, thermogravimetry, differential scanning calorimetry, thermal transpiration, and effusion cells. The results of such analyses provide valuable information regarding the thermodynamic properties of materials.

At Argonne National Laboratory (ANL), we have constructed a system for analyzing evolved gases that will provide information pertinent to the design of off-gas systems for waste glass vitrifiers. The apparatus allows simultaneous determination of the evolved species and the temperatures over which they are evolved. Our goal was to assemble an apparatus that could (1) be used to quickly identify major evolved species from complex mixtures of solids and sludges, (2) measure the temperatures at which the gases were evolved, (3) be used to analyze radioactive and hazardous materials, and (4) be used in a laboratory hood in a manner consistent with material handling procedures.

We have demonstrated the use of the gas evolution apparatus by characterizing the thermal decomposition of several simple sulfates. Sulfates are present as a major component in many waste streams and their behavior during waste vitrification is important to both the production of solid waste forms and to the design off-gas systems. Sulfur has a low solubility in borosilicate glasses (typically on the order of $1 \mathrm{wt} \%$ ) and is expected to require treatment as an off-gas. The decomposition of alkali metal and alkaline earth sulfates has been studied by several researchers, and these sulfates provide useful surrogates for demonstrating the operation of the gas evolution apparatus. 
Depending on the vapor phase composition, temperature, and experimental conditions, sodium sulfate decomposition can occur as (4)

$$
\begin{aligned}
\mathrm{Na}_{2} \mathrm{SO}_{4}(\mathrm{~s} \text { or } \mathrm{l}) & =\mathrm{Na}_{2} \mathrm{SO}_{4}(\mathrm{~g}) \\
\mathrm{Na}_{2} \mathrm{SO}_{4}(\mathrm{~s} \text { or } \mathrm{l}) & =\mathrm{Na}_{2} \mathrm{O}(\mathrm{g})+\mathrm{SO}_{3}(\mathrm{~g}) \\
\mathrm{Na}_{2} \mathrm{SO}_{4}(\mathrm{~s} \text { or } \mathrm{l}) & =2 \mathrm{Na}(\mathrm{g})+\mathrm{SO}_{3}(\mathrm{~g})+1 / 2 \mathrm{O}_{2}(\mathrm{~g}) \\
\mathrm{SO}_{3}(\mathrm{~g}) & =\mathrm{SO}_{2}(\mathrm{~g})+1 / 2 \mathrm{O}_{2}(\mathrm{~g})
\end{aligned}
$$

Sodium sulfate may evaporate without being decomposed, as in reaction (1), if the gas phase contains an abundance of sulfur dioxide and oxygen gas to suppress the formation of sulfur trioxide. Sulfur trioxide formed during the decomposition of sodium sulfate in reactions (2) and (3) is autocatalytically reduced to sulfur dioxide $(5,6)$, as given in reaction (4). Depending on the test conditions, either metallic sodium or sodium oxide may be volatilized as the sulfate decomposes, as in reactions (2) and (3). In a humid atmosphere, volatilized sodium oxide may hydrolyze to form sodium hydroxide as

$$
\mathrm{Na}_{2} \mathrm{O}(\mathrm{g})+\mathrm{H}_{2} \mathrm{O}(\mathrm{g})=2 \mathrm{NaOH}(\mathrm{g})
$$

Alkaline earth sulfates are expected to decompose similarly to sodium sulfate as

$$
\mathrm{CaSO}_{4}(\mathrm{~s})=\mathrm{CaO}(\mathrm{s})+\mathrm{SO}_{3}(\mathrm{~g})
$$

where the sulfur trioxide decomposes to form sulfur dioxide and oxygen as given in reaction (4). Calcium is not expected to volatilize at vitrification temperatures. The decomposition temperatures of alkaline earth sulfates are known to vary with analytical technique, heating rate, quantity, size and shape of particles, ratio of surface area to volume for the sample analyzed, size and shape of the sample crucible, and the atmosphere (6). The decomposition is also affected by the partial pressures of product gases in the vapor phase. In an evacuated system, the heating rate and the pumping speed will affect the partial pressures of product gases above the sample and therefore affect the decomposition rate. Since the pumping speed remains nearly constant in an experimental system, the heating rate is expected to be the most important test parameter affecting the decomposition. Because a wide range of decomposition temperatures has been measured for alkaline earth sulfates under different experimental conditions (7), any comparison of experimental data obtained in different laboratories must be done with caution. 


\section{EXPERIMENTAL}

The apparatus is similar to those described by Gallagher (8). A resistively heated furnace (Luxel RADAK model I) is positioned in a stainless steel vacuum chamber such that the evolved gases are continuously sampled by a quadrupole mass spectrometer (UTI model $100 \mathrm{C}$ ). The entire system is continuously pumped by a turbomolecular pump backed by a mechanical pump to remove evolved gases during the experiment. The heating rate of the furnace is controlled by a programmable temperature control system (Omega model $C N$ 2010). The crucible temperature is monitored by a type $\mathrm{K}$ thermocouple held in contact with the bottom of the crucible. The output signal of the mass spectrometer and the (amplified) thermocouple voltage are connected to both a strip chart recorder and a computer interface.

Experiments are performed by placing a small amount of sample in a $2 \mathrm{cc}$ alumina crucible supplied by the furnace manufacturer (about $5 \mathrm{mg}$ of sample is typically used). The crucible is about $1 \mathrm{~cm}$ in diameter and is positioned about $2 \mathrm{~cm}$ below the mass spectrometer filament. Gases generated as the sample is heated escape from the crucible unimpeded and pass directly through the ionizing region of the mass spectrometer. The axis of the quadrupole is positioned at a right angle to the axis of the crucible. An experiment is conducted by weighing a small amount of sample into the crucible and then loading the crucible in the furnace. (Samples are usually dried in a $90^{\circ} \mathrm{C}$ oven prior to use.) The system is evacuated to a base pressure of about $1 \times 10^{-6}$ torr $\left(1.3 \times 10^{-4} \mathrm{~Pa}\right)$, and the walls of the system are baked at about $150^{\circ} \mathrm{C}$ during the pump-down. The mass spectrometer is programmed to the mass range to be scanned and the desired scanning rate, and the temperature controller is programmed to the desired temperature range and heating rate. The temperature program includes drying the sample at about $150^{\circ} \mathrm{C}$ under vacuum for about 1 hour prior to conducting the experiment. The sample is then heated at a constant rate while the evolved gases are monitored. The mass range is continually scanned as the furnace temperature is ramped linearly. Desorption spectra are generated by plotting the signal at a particular mass peak against the temperature. Of particular interest is identification of desorbed species, their onset temperatures (when a species is first evolved), and their peak desorption temperatures.

Initial tests were conducted without any sample in the crucible to assess the effect on the background gases of heating the furnace and crucible. Three series of experiments were conducted with reagent-grade sulfates and silica to characterize 
various aspects of the operation of the apparatus, the decomposition behavior of sulfate, and the vitrification of sodium sulfate with silica. Reagent-grade, powdered chemicals were used in all experiments. The chemicals were sieved through a 100 mesh (U.S. Standard) sieve such that all particles were smaller than about $140 \mu \mathrm{m}$. The first series of experiments was conducted to demonstrate the effects of the heating rate on the evolution of gases generated during the decomposition of sodium sulfate. Gas evolution was monitored as a constant amount of sodium sulfate was heated to about $1200^{\circ} \mathrm{C}$ at heating rates of 1,5 , and $10^{\circ} \mathrm{C} / \mathrm{min}$. The second series of experiments compared the decomposition and gas evolution behavior of magnesium, calcium, and barium sulfates at heating rates of 1 and $10^{\circ} \mathrm{C} / \mathrm{min}$. The third series of experiments characterized the evolution of gases as three mechanical mixtures of sodium sulfate and silica were vitrified. The resulting glasses were analyzed using a scanning electron microscope with associated energy dispersive $X$-ray spectroscopy (SEM/EDS) to determine the composition of the glasses formed.

\section{RESULTS AND DISCUSSION}

\section{Background Gases}

Experiments were performed with empty crucibles to determine the behavior of the system background to assure that background gases did not interfere with the detection of gases evolved during sample decomposition. The mass range between about $\mathrm{m} / \mathrm{e}=2$ and $\mathrm{m} / \mathrm{e}=150$ was repeatedly scanned as the empty crucible was heated from about 200 to $1200^{\circ} \mathrm{C}$. (The fragments detected by the mass analyzer are expressed in terms of the mass to charge ratio, i.e., $\mathrm{m} / \mathrm{e}$. Fragments are identified by assuming they are singly charged, and doubly charged species are generally ignored in the interpretation. Fragments having common $\mathrm{m} / \mathrm{e}$ values are distinguished by means of known cracking patterns. For example, $\mathrm{O}_{2}{ }^{+}$and $\mathrm{S}^{+}$both have $\mathrm{m} / \mathrm{e}=32$. They can be distinguished through the intensity of the $\mathrm{O}^{+}$peak at $\mathrm{m} / \mathrm{e}=16$, since the $\mathrm{O}_{2}{ }^{+}$and $\mathrm{O}^{+}$peaks derived from $\mathrm{O}_{2}$ maintain a constant ratio.

Residual water $(\mathrm{m} / \mathrm{e}=18)$ that was not removed from the system during the initial bake-out is vaporized as the system is heated. The amount of water continually decreases as the furnace heats, while the amounts of hydrogen gas, carbon monoxide/nitrogen, and carbon dioxide ( $\mathrm{m} / \mathrm{e}=2,28,44$, respectively) continually increase as the furnace heats. No signal is detected at masses corresponding to $\mathrm{SO}^{+}, \mathrm{SO}_{2}{ }^{+}$, or $\mathrm{SO}_{3}{ }^{+}(\mathrm{m} / \mathrm{e}=48,64$, or 80$)$, which are the major species that will be evolved as the sulfates decompose. Thus, the background gases evolved as the system equipment 
and crucible area heated during an experiment will not interfere with the detection of gases evolved during decomposition of the sulfates.

Decomposition of $\mathrm{Na}_{2} \mathrm{SO}_{4}$

Decomposition of pure sodium sulfate resulted in the evolution of $\mathrm{Na}^{+}, \mathrm{O}^{+}, \mathrm{O}_{2}^{+}, \mathrm{S}^{+}$, $\mathrm{SO}^{+}$, and $\mathrm{SO}_{2}{ }^{+}$. No peak corresponding to $\mathrm{SO}_{3}{ }^{+}(\mathrm{m} / \mathrm{e}=80)$ could be detected. This indicates that reaction (4) proceeds to the right. The normalized evolution profiles of $\mathrm{SO}_{2}{ }^{+}$as sodium sulfate was decomposed in tests conducted at heating rates of 1,5 , and $10^{\circ} \mathrm{C} /$ minute are shown in Figure 1. The amounts of $\mathrm{S}^{+}$and $\mathrm{SO}^{+}$generated in the test conducted at $10^{\circ} \mathrm{C} /$ minute are also shown. $\mathrm{S}^{+}$and $\mathrm{SO}^{+}$species are produced by the cracking of $\mathrm{SO}_{2}$ by the mass analyzer (9).

The peak temperature for $\mathrm{SO}_{2}{ }^{+}$evolution is seen to increase significantly with the heating rate, as shown in Figure 2. This behavior occurs because the decomposition rate is lower than the heating rate. The data are well fitted by a straight line having an intercept at a heating rate of $0^{\circ} \mathrm{C} / \mathrm{min}$ at about $905^{\circ} \mathrm{C}$. This intercept value is only slightly above the melting temperature of anhydrous sodium sulfate, which is $884^{\circ} \mathrm{C}(10)$. These results suggest that sodium sulfate decomposes soon after it melts. The total time required for the sodium sulfate to completely decompose can be calculated by multiplying the heating rate by the difference between the peak temperature at that heating rate and $905^{\circ} \mathrm{C}$. For example, the peak temperature at a heating rate of $10^{\circ} \mathrm{C} / \mathrm{min}$ is about $1040^{\circ} \mathrm{C}$, so that the sample has decomposed in about 13.5 minutes. About 10-15 minutes are required to completely decompose the $5 \mathrm{mg}$ sample at each heating rate. The rapid decomposition of sodium sulfate slightly above its melting temperature is consistent with calculations done using SOLGAS (11), which show that the equilibrium pressure of sulfur dioxide increases by nearly five orders of magnitude after sodium sulfate melts.

In addition to affecting the peak temperature, the heating rate (in conjunction with the scan rate of the mass analyzer) also determines how often a particular mass peak is sampled. For example, the sample temperature increases about 2,10 , or $20^{\circ} \mathrm{C}$ between data points at heating rates of 1,5, or $10^{\circ} \mathrm{C} / \mathrm{min}$ at a scan rate of about $150 \mathrm{amu} / \mathrm{min}$. Thus, the uncertainty in the measured peak temperature is greatest at the highest heating rate. Also, it is likely that higher heating rates will result in a greater difference between the actual sample temperature and the temperature measured at the outside of the crucible by the thermocouple.

Finally, the onset temperature for $\mathrm{SO}_{2}{ }^{*}$, i.e., the temperature at which the signal first differs from zero at the mass of interest, occurs at about $850^{\circ} \mathrm{C}$ at all heating rates. 
The onset temperature is independent of the decomposition rate or the amount of sample being tested.

The shape of the evolution curve provides some insight into the process that occurs as the sample is heated. The amount of $\mathrm{SO}_{2}$ evolved increases slowly with time (and temperature) initially, then suddenly increases to a maximum, and then decreases. This "peak" in the spectrum occurs because the sample volume is finite. That is, the peak occurs because the sample completely decomposes and becomes depleted of the evolved gas. The high-temperature tail of the peak occurs when the evolution rate drops below the pumping speed of the system. Thus, comparison of peak temperatures has meaning only when the same number of moles of sample is tested.

Another consideration is that the sodium sulfate and the alumina crucible may have reacted to form sodium aluminate. The chemical reaction between sodium sulfate and alumina can be written as

$$
\mathrm{Al}_{2} \mathrm{O}_{3}(\mathrm{~s})+\mathrm{Na}_{2} \mathrm{SO}_{4}(\mathrm{l})=\mathrm{Na}_{2} \mathrm{Al}_{2} \mathrm{O}_{4}(\mathrm{~s})+\mathrm{SO}_{3}(\mathrm{~g})
$$

This reaction releases the same decomposition gases as the simple decomposition of sodium sulfate, so the crucible may catalyze the decomposition of the molten salt. Gases generated through interaction with the crucible cannot be distinguished from other gases on the basis of the data.

Decomposition of $\mathrm{CaSO}_{4}, \mathrm{MgSO}_{4}$, and $\mathrm{BaSO}_{4}$

Heating these alkaline earth sulfates generated $\mathrm{SO}_{2}$ and $\mathrm{O}_{2}$ gases (and $\mathrm{SO}^{+}$and $\mathrm{S}^{+}$cracking fragments in the mass analyzer). $\mathrm{No} \mathrm{SO}_{3}$ was detected during the decomposition of these alkaline earth sulfates. This is contrary to the findings of Hildenbrand et al., where $\mathrm{SO}_{3}$ was detected when large orifices were used in their effusion device and total conversion of $\mathrm{SO}_{3}$ to $\mathrm{SO}_{2}$ and $\mathrm{O}_{2}$ during the decomposition only occurred when small orifices were used (5). Our apparatus does not use an orifice and the release of gas is only constrained by the crucible. Figure 3 shows the integrated amounts of $\mathrm{SO}_{2}$ detected by the mass analyzer during the decomposition of $\mathrm{CaSO}_{4}$, $\mathrm{MgSO}_{4}, \mathrm{BaSO}_{4}$ for experiments conducted at a heating rate of $1^{\circ} \mathrm{C} / \mathrm{min}$. (The inflection points of the curves in Figure 3 correspond to the peaks in the spectra in Figure 2.) The results of experiments with $\mathrm{Na}_{2} \mathrm{SO}_{4}$ are included for comparison. As the heating rate increased, the curve for each alkaline earth sulfate shifted to a higher temperature, but the shape of the curve changed little. This means that both the onset temperature and the peak temperature change with the heating rate. In contrast, the shape of the $\mathrm{Na}_{2} \mathrm{SO}_{4}$ 
curve became flatter at the higher heating rates. The onset and peak temperatures are summarized in Table 1. Values measured at a heating rate of $1^{\circ} \mathrm{C} / \mathrm{min}$ are lower than those measured at a heating rate of $10^{\circ} \mathrm{C} / \mathrm{min}$. Table 1 also gives the melting temperatures of the different sulfates. Only the melting temperature of $\mathrm{NaSO}_{4}$ is within the temperature range tested. The alkaline earth sulfates decompose before melting. This may explain the different effect the heating rate has on the shapes of the curves in Figure 3. The measured decomposition temperatures for $\mathrm{CaSO}_{4}$ and $\mathrm{MgSO}_{4}$ at the higher heating rate are in fair agreement with those measured by others at a similar heating rate (e.g., $895^{\circ} \mathrm{C}$ for $\mathrm{MgSO}_{4}$ and $1149^{\circ} \mathrm{C}$ for $\mathrm{CaSO}_{4}$ ) (7). Decomposition temperatures have been measured to range between about 800 and $900^{\circ} \mathrm{C}$ for $\mathrm{MgSO}_{4}$, and between about $1000^{\circ} \mathrm{C}$ and $1200^{\circ} \mathrm{C}$ for $\mathrm{CaSO}_{4}$ in dry air, dry nitrogen, and in vacuum $(6,7)$. In our apparatus, decomposition of these sulfates occurs at the lower end of these ranges. Barium sulfate has been reported to melt without decomposing (10), although Figure 3 shows a measurable release of sulfur dioxide at temperatures above about $900^{\circ} \mathrm{C}$. These results demonstrate how the measured decomposition temperatures may vary with the experimental conditions.

Decomposition and Vitrification of Mixtures of $\mathrm{Na}_{2} \mathrm{SO}_{4}$ and $\mathrm{SiO}_{2}$

As expected, the results of experiments with only silica in the crucible are identical to that obtained with no sample in the crucible. That is, silica does not melt or decompose upon being heated to about $1200^{\circ} \mathrm{C}$. The results of experiments in which different amounts of $\mathrm{Na}_{2} \mathrm{SO}_{4}$ and $\mathrm{SiO}_{2}$ are heated together are shown in Figure 4. The results shown in Figure 4 have been normalized to the total amount of $\mathrm{SO}_{2}^{+}$produced in each test to facilitate comparison. Mixtures of $5.3 \mathrm{mg} \mathrm{Na}_{2} \mathrm{SO}_{4}+6.7 \mathrm{mg} \mathrm{SiO}, 5.3 \mathrm{mg}$ $\mathrm{Na}_{2} \mathrm{SO}_{4}+2.2 \mathrm{mg} \mathrm{SiO}_{2}$, and $5.3 \mathrm{mg} \mathrm{Na}_{2} \mathrm{SO}_{4}+0.7 \mathrm{mg} \mathrm{SiO}$ were heated. These mixtures have $\mathrm{Na}_{2} \mathrm{SO}_{4}: \mathrm{SiO}_{2}$ molar ratios of $1: 3,1: 1$, and 1:0.33, respectively, and all tests have the same number of moles of $\mathrm{Na}_{2} \mathrm{SO}_{4}$. The results of heating $5.3 \mathrm{mg}$ of $\mathrm{Na}_{2} \mathrm{SO}_{4}$ alone are included in the plot for comparison. Less gas was evolved in experiments conducted with smaller amounts of silica, even though the same amount of sodium sulfate was present in all tests. The onset temperatures are similar in all mixtures, but the inflection points (which correspond to the peak temperatures) occur for lower temperatures at lower $\mathrm{Na}_{2} \mathrm{SO}_{4}: \mathrm{SiO}_{2}$ ratios. The decomposition may occur via reaction (2) or by a reaction between silica and melted sodium sulfate, as follows

$$
\mathrm{Na}_{2} \mathrm{SO}_{4}(\mathrm{l})+\mathrm{SiO}_{2}(\mathrm{~s})=\mathrm{Na}_{2} \mathrm{SiO}_{3}(\mathrm{~s})+\mathrm{SO}_{3}(\mathrm{~g})
$$


Thus, the addition of silica may promote the decomposition of sodium sulfate, and an increase in the surface area of silica leads to the evolution of more sulfur dioxide.

An important finding of these tests is that sulfur dioxide and oxygen are the dominant gases evolved during the decomposition of sodium sulfate in both the presence and absence of silica. The fact that $\mathrm{SO}_{3}$ is completely reduced to $\mathrm{SO}_{2}$ during vitrification is important due to the simultaneous generation of $\mathrm{O}_{2}$ and the maintenance of an oxidizing atmosphere which will affect both the glass and other off-gases. Further work is needed to determine how other components present in waste glasses, such as boron and aluminum, will affect the off-gases.

The glasses formed by heating the mixtures to about $1200^{\circ} \mathrm{C}$ were analyzed using SEM/EDS. The crucibles were cut in half axially, and the composition of the glass was determined in several locations. The glasses formed from all three mixtures were inhomogeneous and had compositions of the form $\mathrm{Na}_{2} \mathrm{O} \cdot \times \mathrm{SiO}_{2}$, where $\mathrm{x}$ was 3 to 10 mol\%. Very little sulfur was detected in the glass; it was found only in regions that were also sodium-rich. These regions are probably small inclusions of unreacted sodium sulfate that became trapped as the glass solidified during cooling.

Analysis of the glass adjacent to the alumina crucible suggests that a small amount of aluminum (a few weight percent) has entered the glass. Aluminum was detected only very near the crucible. (Aluminum was found far enough away from the crucible that it could not be due to overlap of the sampled volume and the crucible itself.) The small amount of interaction between the melt and the crucible is assumed not to have affected the gas evolution.

The gas evolution apparatus has been placed in a vacuum frame hood for analysis of off-gases generated during the vitrification of hazardous and radioactive wastes. We envision routinely analyzing off-gases during development of glass waste forms in our laboratory. Work is in progress to characterize off-gases from several waste streams, including spent commercial zeolite catalysts, contaminated HEPA filters, retention tank sludges, etc. In addition to information regarding the efficiency of vitrification treatment to stabilize volatile components, these analyses are needed to address safety issues during bench-scale developmental work.

\section{CONCLUSIONS}

We have demonstrated the use of an evolved-gas analysis system designed to analyze off-gases during vitrification of hazardous wastes. The system was used to characterize the decomposition behavior of sodium sulfate, alkaline earth sulfates, and 
mixtures of sodium sulfate and silica. Both the onset temperatures (i.e., the temperatures at which decomposition begins) and the peak temperatures (i.e., the temperatures at which decomposition was complete) were characterized at different heating rates and for different mixtures of sodium sulfate and silica. The onset temperatures for the decomposition of pure sodium sulfate and for mixtures of sodium sulfate and silica were not significantly affected by the heating rate. However, the onset temperatures for the decomposition of alkaline earth sulfates was affected by the heating rate. The difference arises because sodium sulfate melts before decomposing, while the alkaline earth sulfates do not melt.

\section{ACKNOWLEDGMENTS}

The authors thank Irving Johnson for valuable discussions regarding SOLGAS.

This work was supported by the U.S. Department of Energy, Office of Technology Development, under contract W-31-109-ENG-38.

\section{DISCLAIMER}

\footnotetext{
This report was prepared as an account of work sponsored by an agency of the United States Government. Neither the United States Government nor any agency thereof, nor any of their employees, makes any warranty, express or implied, or assumes any legal liability or responsibility for the accuracy, completeness, or usefulness of any information, apparatus, product, or process disclosed, or represents that its use would not infringe privately owned rights. Reference herein to any specific commercial product, process, or service by trade name, trademark, manufacturer, or otherwise does not necessarily constitute or imply its endorsement, recommendation, or favoring by the United States Government or any agency thereof. The views and opinions of authors expressed herein do not necessarily state or reflect those of the United States Government or any agency thereof.
} 


\section{REFERENCES}

1. Equity Associates. Vitrification Technologies for Treatment of Hazardous and Radioactive Waste, prepared for U.S. Environmental Protection Agency. Report No. EPA/625/R-92/002 PB92-201110, May 1992.

2. Plodinec, M.J. Development of Glass Compositions for Immobilization of Savannah River Plant Waste. Scientific Basis for Nuclear Waste Management Vol. 1, 31 (1979).

3. Pegg, I.L, Saad, E.E., Feng, X., Adiga, R.B., Freeborn, W.P., and Macedo, P.B. Product Models for the Vitrification of West Valley High-Level Wastes. Mat. Res. Soc. Symp. Proc. 127, (1989).

4. Cubicciotti, D. and Keneshea, F.J. Thermodynamics of Vaporization of Sodium Sulfate. High Temperature Science 4, 32 (1970).

5. Hildenbrand, D.L., Lau, K.H., Brittain, R.D. Mechanistic Aspects of Metal Sulfate Decomposition Processes. High Temperature Science 26, 427 (1990).

6. Tagawa, H. and Koga, N. Thermal Decomposition Temperatures of Metal Sulfates. Thermochimica Acta $\underline{80}, 23$ (1984).

7. Ostroff, A.G. and Sanderson, R.T. Thermal Stability of Some Metal Sulphates. J. Inorg. Nucl. Chem. 9: 45 (1959).

8. Gallagher, P.J. An Evolved Gas Analysis System. Thermochimica Acta 26, 175 (1978).

9. Ficalora, P.J., Uy, O.M., Muenow, D.W., and Margrave, J.L. Mass Spectrometric Studies at High Temperatures: XXIX,Thermal Decomposition and Sublimation of Alkali Metal Sulfates. J. Amer. Ceram. Soc. 51, 574 (1968).

10. K.H. Stern and E.L. Weise. High Temperature Properties and Decomposition of Inorganic Salts: Part 1. Sulfates, National Standard Reference Data Series. National Bureau of Standards (1966).

11. T.M. Besmann. SOLGASMIX-PV, A Computer Program to Calculate Equilibrium Relationships in Complex Chemical Systems. Oak Ridge National Laboratory, Report No. ORNLTM-5775, April 1977. 
Table 1. Measured Onset and Peak Temperatures, in ${ }^{\circ} \mathrm{C}$

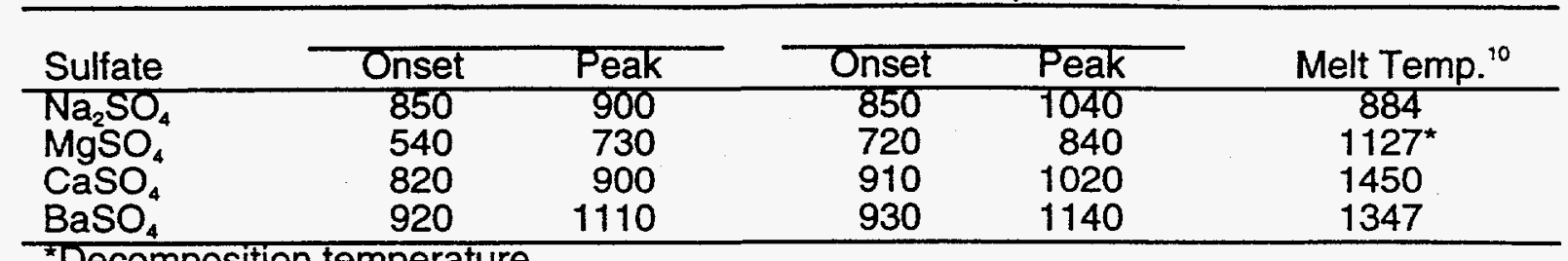

"Decomposition temperature. 


\section{FIGURE CAPTIONS}

Figure 1. Evolution Profiles of $\mathrm{SO}_{2}{ }^{+}$during the Decomposition of Sodium Sulfate at Heating Rates of 1,5 , and $10^{\circ} \mathrm{C} / \mathrm{min}$ (normalized to the peak value of $\mathrm{SO}_{2}{ }^{+}$). The profiles within the curve at $10^{\circ} \mathrm{C} / \mathrm{min}$ are for the $\mathrm{S}^{+}$and $\mathrm{SO}^{+}$species.

Figure 2. Temperature of $\mathrm{SO}_{2}{ }^{+}$Peak vs. Heating Rate during the Decomposition of Sodium Sulfate.

Figure 3. Total Amount of $\mathrm{SO}_{2}{ }^{+}$Evolved from Various Sulfates vs. Temperature. Profiles were collected at a heating rate of $1^{\circ} \mathrm{C} / \mathrm{min}$.

Figure 4. Normalized Amount of $\mathrm{SO}_{2}{ }^{+}$Evolved from Mixtures of $5.2 \mathrm{mg} \mathrm{NaSO} 4$ and $0.0,0.7,2.2$, and $6.7 \mathrm{mg}$ of $\mathrm{SO}_{2}$ vs. Temperature. Profiles were collected at a heating rate of $10^{\circ} \mathrm{C} / \mathrm{min}$. 


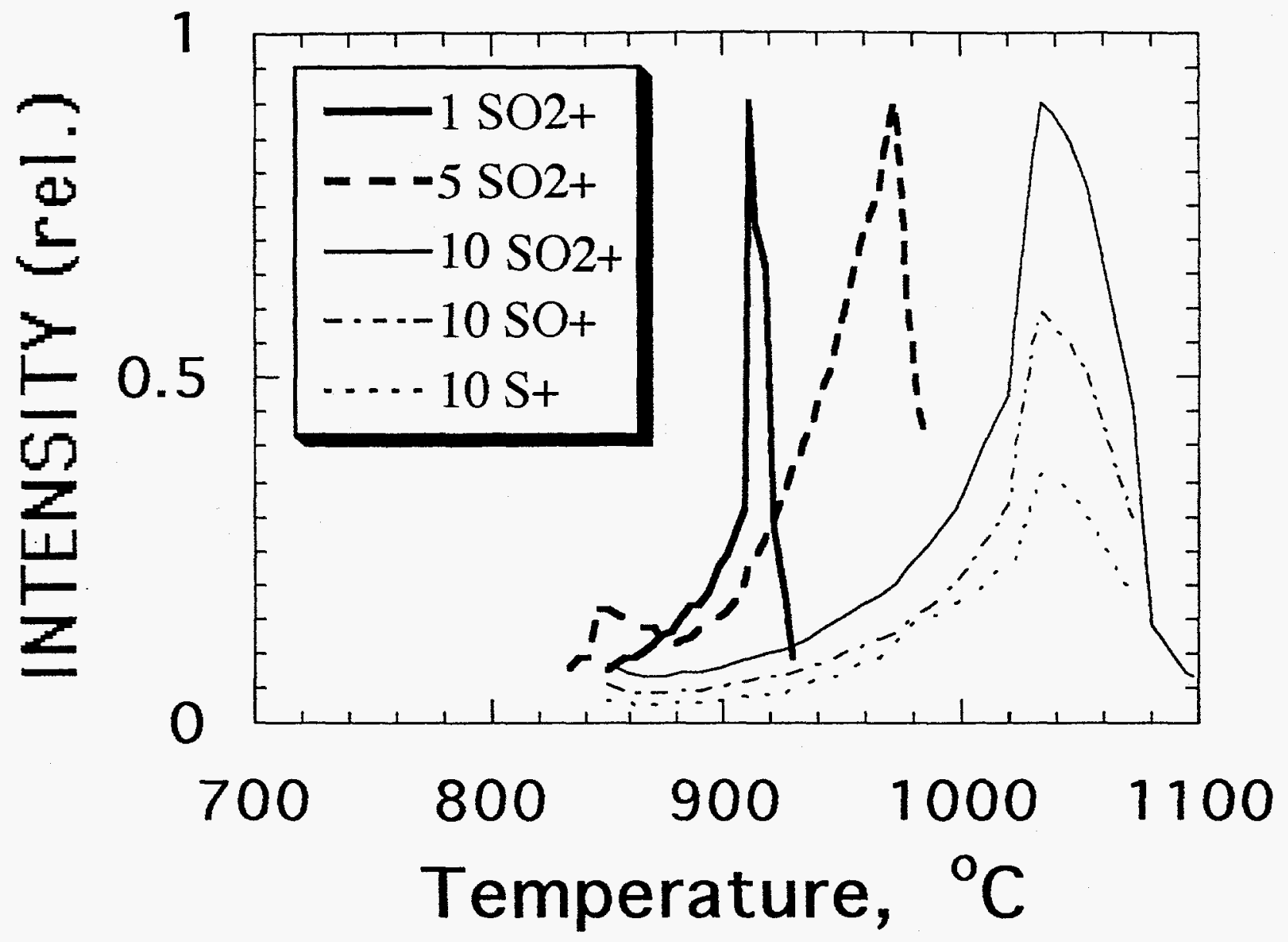

Fic 


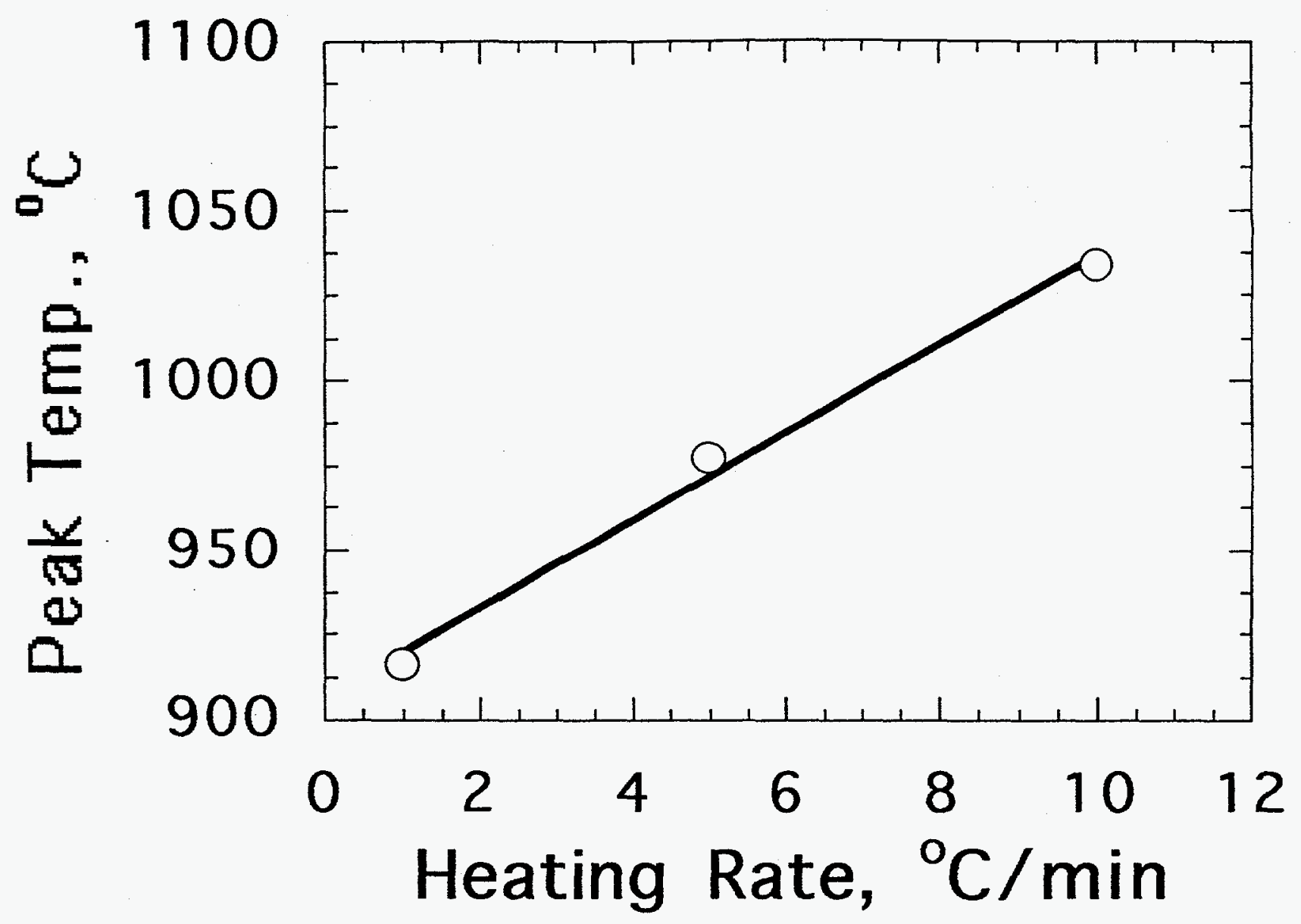




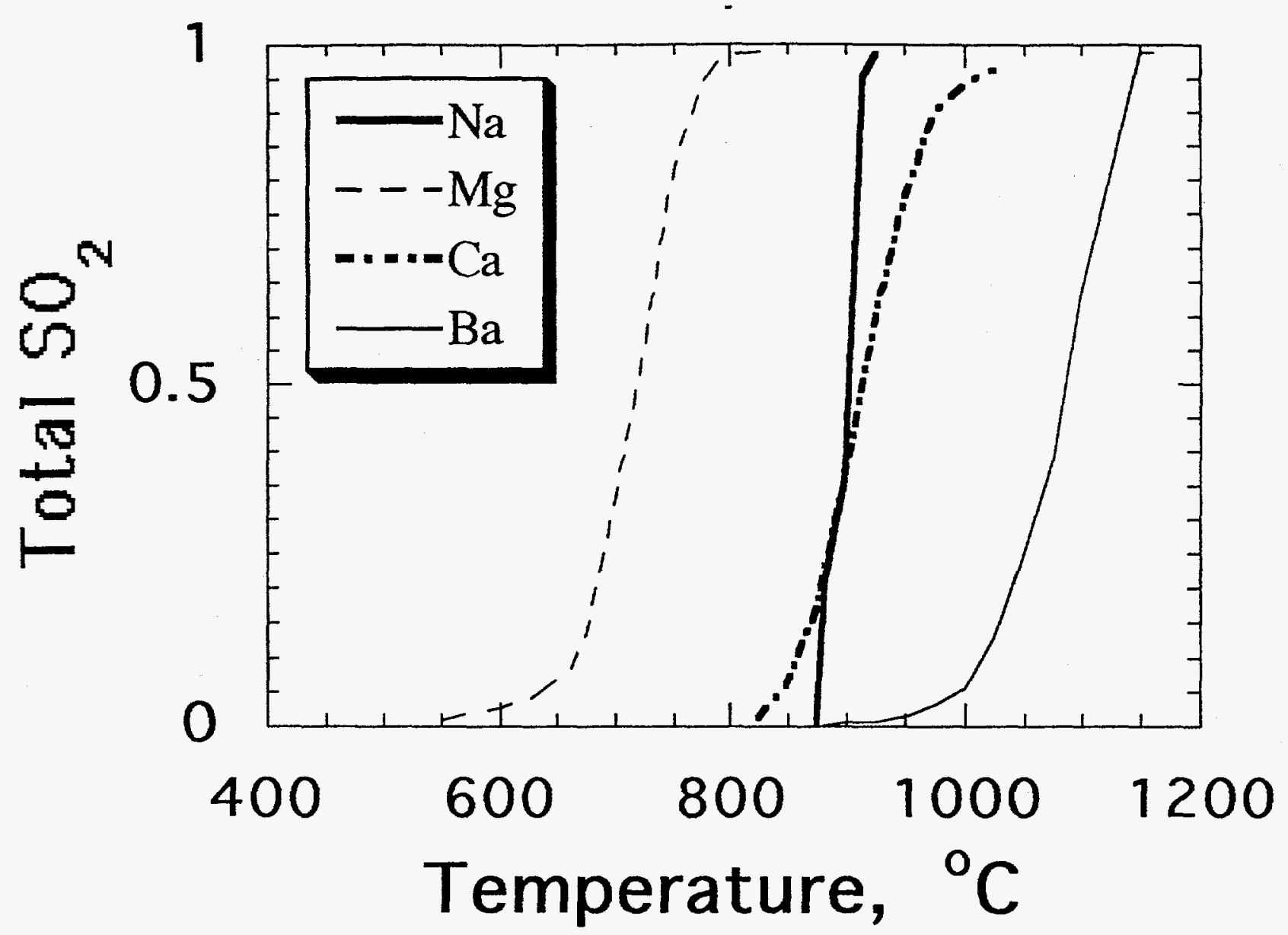

FEES 


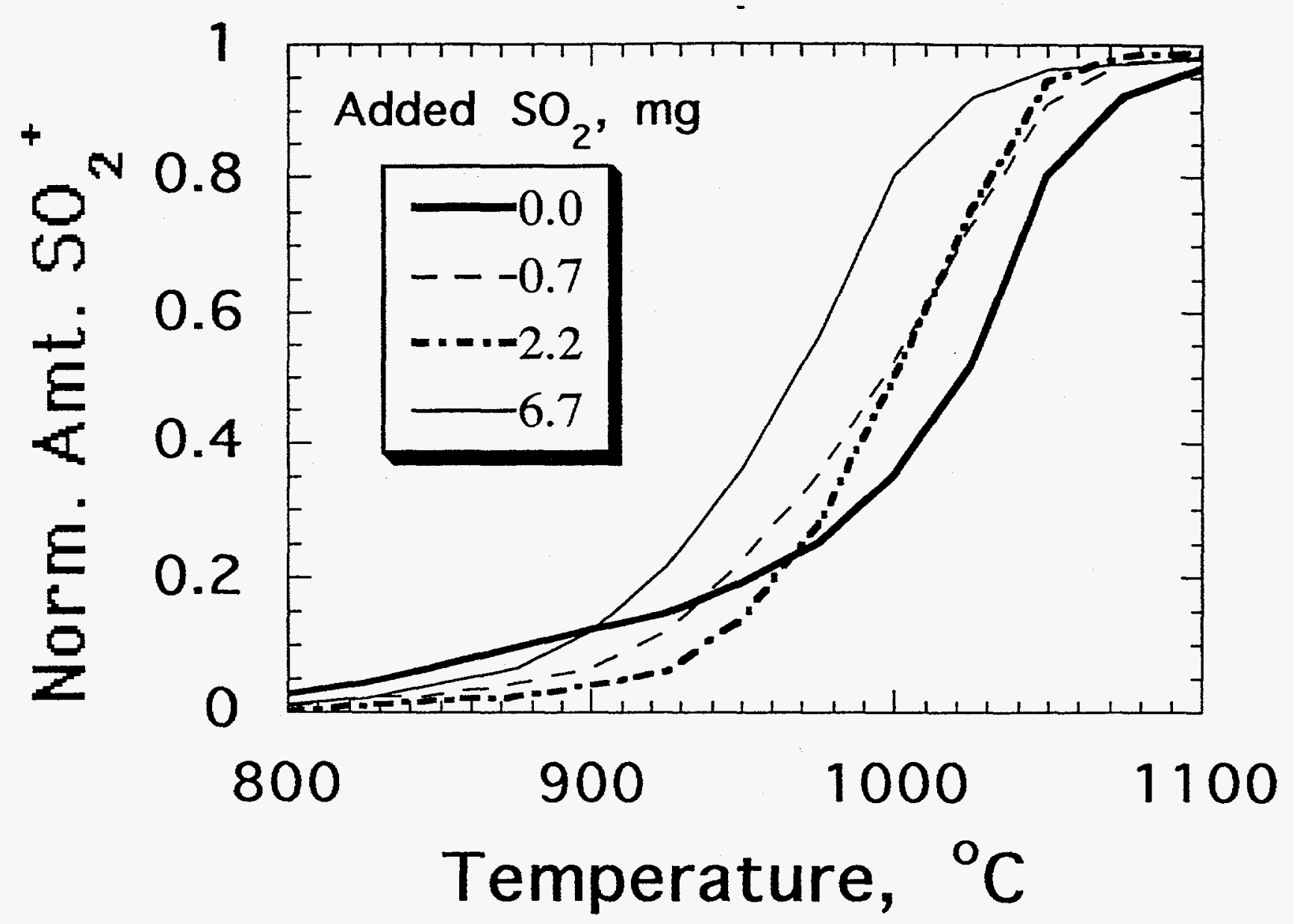

$F: 4$ 